Notes

\title{
NSC-87877 Inhibits Cdc25A and Cdc25B
}

\author{
Mina Song and Sayeon Cho \\ College of Pharmacy and Research Institute for Translational System Biomics, Chung-Ang Lniversity, \\ Seoul 156-756. Korea. "E-mail: svchoiácau.ackn \\ Received February 18, 2009, Accepted 1 farch 2, 2009
}

Key Words: Cdc25, NSC-87877. PTP inhibitor

The protein phosphorylation level inside cells is controlled by the balance between activities of protein kinases and phosphatases. Protein phosphorylations are involved in the regulation of diverse processes. such as cellular metabolism. proliferation, differentiation. growth. migration, and invasion of normal and malignant cells. ${ }^{1.2}$ The protein tyrosine phosphatase (PTP) superfamily comprises over 100 proteins. Based on the amino acid sequences of their catalytic sites. PTPs are divided into the classical dual-specificity protein tyrosine phosphatases (DUSPs), ty rosine-specific low molecular weight phosphatases. the Cdc 25 family, and eyes absent (EyA) protein. ${ }^{3}$

Recent studies indicate that modulation of PTP enzymatic activity could have a role in regulating a large spectrum of cellular functions and disease susceptibility. ${ }^{4}$ Thus. chemical compounds that regulate the activity of PTPs have been extensively screened to be used as potent therapeutic reagents.

Cell division cycle 25 ( $\mathrm{Cdc} 25$ ) phosphatases are members of PTP subfamily. which dephosphorylate a phosphorylated-threonine or -ty rosine residue of the same protein substrate and are essential regulators of the cell cycle. The three human Cdc25 isoforms (A. B. and C) have been reported to control different phases of the cell cycle. The overexpression of $\mathrm{Cdc} 25 \mathrm{~A}$ and $\mathrm{Cdc} 25 \mathrm{~B}$ has been reported in numerous human tumors and linked to oncogenic transformation and human cancers in a variety of ways. ${ }^{5.8 .8} \mathrm{Cdc} 25$ phosphatases are inactivated by various mechanisms. including degradation and inhibition."

8-Hydroxy-7-(6-sulfonaphthalen-2-yl)diazeny l-quinoline5 -sulfonic acid (NSC-87877) was originally identified as a potent inhibitor of $\mathrm{Src}$ homology region 2 (SH2) domaincontaining phosphatase 1 (SHP-1) and SHP-2 PTPs (Fig. 1) ${ }^{10}$<smiles>O=[N+]([O-])c1cc(/N=N/c2ccc3cc(S(=O)(=O)O)ccc3c2)c(O)c2ncccc12</smiles>

Figure 1. Chemical structure of NSC-87877.
They contain two $\mathrm{SH} 2 \mathrm{~N}$-terminal domains and a C-terminal protein tyrosine phosphatase domain. SHP-2 is involved in the function of several growth factors and metabolic pathways and acts in disease pathways such as leukemia. diabetes. neurodegeneration, and cancer. ${ }^{11,12}$ Since there might be more phosphatases that can be targets of NSC-87877. we screened 15 PTPs by in vitro phospluatase assays to identify PTPs that are inhibited by NSC-87877. An inhibition curve was plotted for each PTP and the inhibitory concentration 50 ( $\mathrm{IC}_{51}$ ) values were calculated. As shown in Table 1. Cdc25 A and Cdc25B were inhibited with $\mathrm{IC}_{51}$ value of $0.6 \pm 0.004 \mu \mathrm{M}$ and $1.29 \pm$ $0.35 \mu \mathrm{M}$, respectively. The $\mathrm{IC}_{5 i}$, values for other PTPs were higher than $50 \mu \mathrm{M}$. suggesting that NSC-87877 has low inhibitory effect on these phosphatases.

We examined the inhibitory effects of NSC-87877 on $\mathrm{Cdc} 25 \mathrm{~A}$ and $\mathrm{Cdc} 25 \mathrm{~B}$. When both phosphatases were treated with various concentrations of NSC-87877, phosphatase activities were decreased by the inhibitor in a dose-dependent manner (Fig. 2A and B). Molecular modeling and site-directed mutagenesis studies suggested that NSC-87877 binds to the catalytic cleft of SHP-2. Kinetic studies with NSC-87877 and $\mathrm{Cdc} 25$ s revealed competitive inhibitions as shown by the Lineweaver-Burk plot. suggesting that NSC-87877 binds to the catalytic cleft of $\mathrm{Cdc} 25 \mathrm{~A}$ and $\mathrm{Cdc} 25 \mathrm{~B}$ in the same manner as SHP-2 (Fig. $3 \mathrm{~A}$ and $\mathrm{B}$ ). The $K_{\mathrm{m}}$ values of both $\mathrm{Cdc} 25 \mathrm{~A}$ and $\mathrm{Cdc} 25 \mathrm{~B}$ for OMFP were $66 \mu \mathrm{M}$ and $13 \mu \mathrm{M}$. respectively. The $K_{\mathrm{i}}$ values for $\mathrm{Cdc} 25 \mathrm{~A}$ and $\mathrm{Cdc} 25 \mathrm{~B}$ were $0.59 \mu \mathrm{M}$ and 1.28 $\mu \mathrm{M}$. respectively.

In the present study. we screened PTPs to search for targets of NSC -87877 by performing in vitro PTP activity assays. We

Table 1. Inhibition of PTPs by NSC-87877. Inhibitory IC s $_{50}$ of enzyme activity was detemined for the various PTPs including PTPRO, PTPRE, PTPN7, Cdc25A and Cdc25B. Datá are presented as mean \pm S.E.M.

\begin{tabular}{cc}
\hline Protein tyrosine phosphatase & $\mathrm{IC} \mathrm{s}_{0}(\mu \mathrm{M})$ \\
\hline PTPRO & $>50$ \\
PTPRE & $>50$ \\
PTPN7 & $>50$ \\
$\operatorname{cdc} 25 \mathrm{~A}$ & $0.60 \pm 0.004(\mathrm{n}=3)$ \\
cdc25B & $1.29 \pm 0.35(\mathrm{n}=3)$ \\
\hline
\end{tabular}




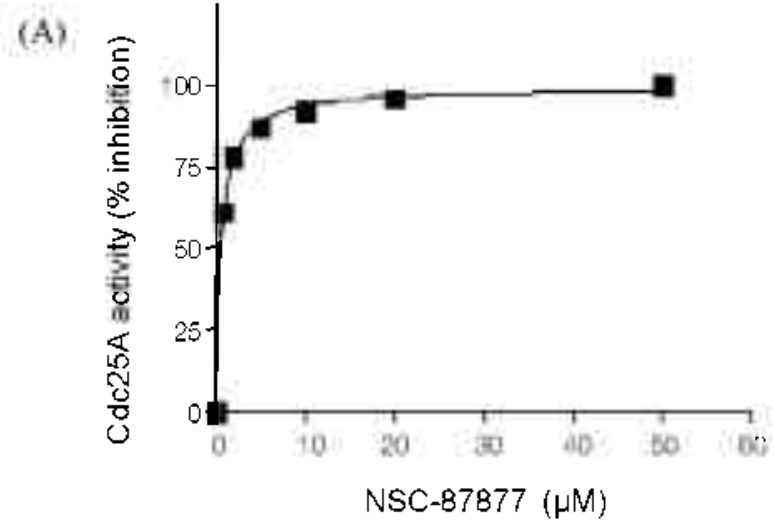

(B)

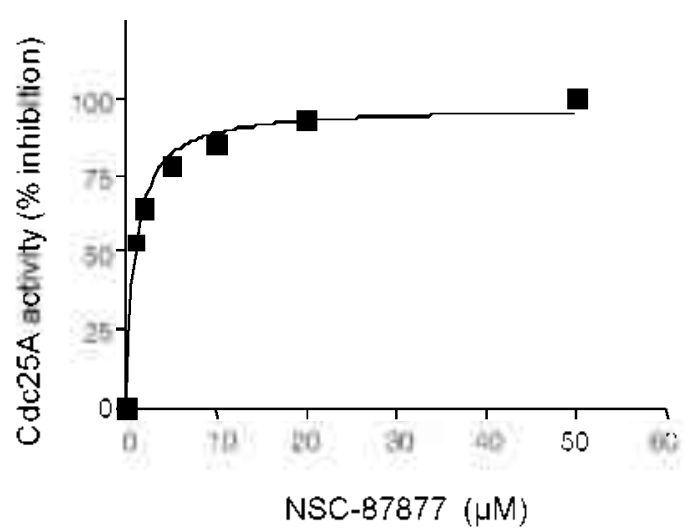

Figure 2. Inhibitory effect of NSC-7877 in Cdc25 A and Cdc25B. (A) $\operatorname{Cdc} 25 \mathrm{~A}$ and was incubated with varions concentrations of NSC- 87877 at $37^{\circ} \mathrm{C}$ for $30 \mathrm{~min}$, respectivelv. Fluorescence emission from the product was measured with a multiwell plate reader as described in Esperimental section. (B) The inhibitory effect of NSC-87877 on Cdc25B was deternined as described in (A).

found that NSC-87877 inhibits activity of $\mathrm{Cdc} 25 \mathrm{~A}$ and $\mathrm{Cdc} 25 \mathrm{~B}$ in a dose-dependent manner and is a potent competitive-inhibitor of $\mathrm{Cdc} 25 \mathrm{~A}$ and $\mathrm{Cdc} 25 \mathrm{~B}$. The overexpression of $\mathrm{Cdc} 25 \mathrm{~A}$ and $\mathrm{Cdc} 25 \mathrm{~B}$ has been reported in various cancers. such as breast cancer, prostate cancer. pancreatic ductal adenocarcinoma. non-Hodgkin's lymphoma. and non-smallcell lung cancer. ${ }^{6}$ It has recently been suggested that C dc25 inhibitors were able to reduce the growth of pancreatic cell lines that expressed high levels of Cdc25B. ${ }^{13}$ For these reasons. we suggest that inhibition of the $\mathrm{Cdc} 25 \mathrm{~A}$ and Cdc25B using NSC-87877 may be a novel therapeutic approach for the treatment of cancer

\section{Experimental Section}

Recombinant PTP proteins. Plasmids for expression of $6 \mathrm{x}$ His-tagged proteins of human PTPRO, PRPRE and PTPN7 were constructed in pET-28a (+) and transformed into BL2 I(DE3)-RI E.coli. Plasmids for expression of glutathione S-transferase (GST)-PTP fusion proteins of human Cdc25A and $\mathrm{Cdc} 25 \mathrm{~B}$ were constructed in $\mathrm{pGEX}$ and transformed into BL21(DE3)-RIL E.coli. Expression of recombinant protein was induced with ImM isopropy l- $\beta$-D-thiogalactopyranoside at $37^{\circ} \mathrm{C}$ or $30^{\circ} \mathrm{C}$ for $8 \sim 10 \mathrm{~h}$. Cells were harvested and then
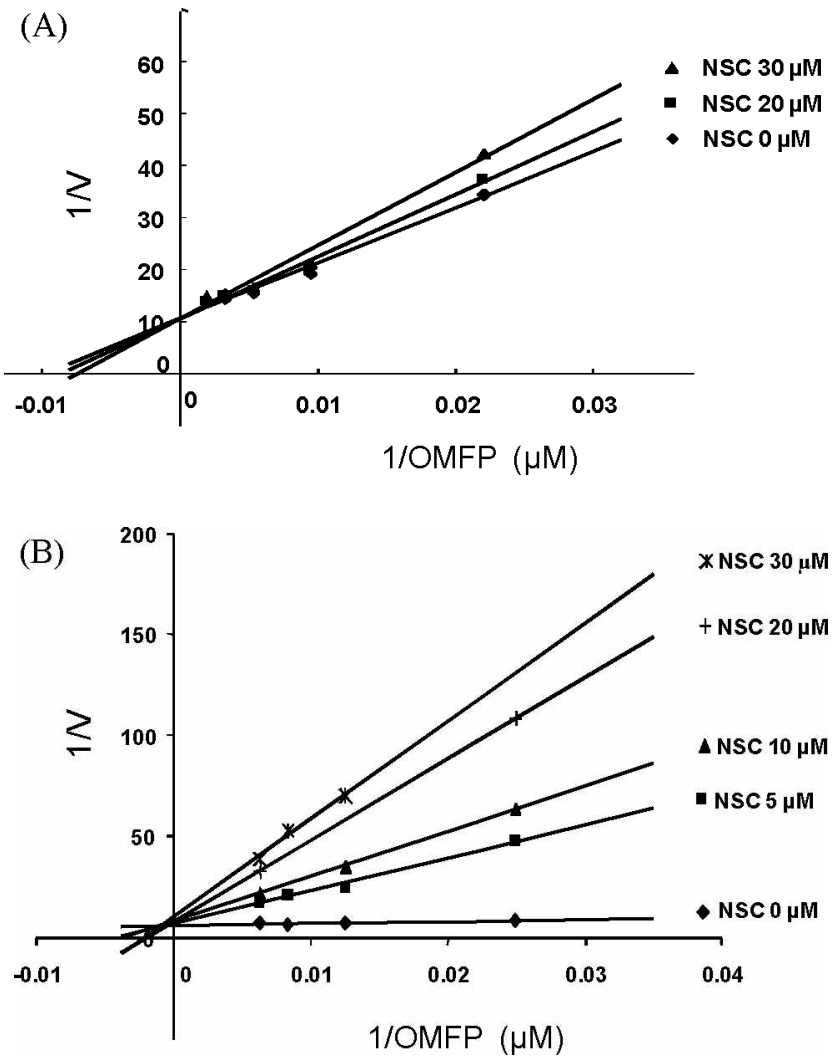

Figure 3. Kinetic analysis of $\mathrm{Cdc} 25 \mathrm{~A}$ and $\mathrm{Cdc} 25 \mathrm{~B}$ irhibition by NSC-87877. Lineweaver-Burk plots for inhibition of Cdc25A (A) and $\mathrm{Ccd} 25 \mathrm{~B}$ (B) were generated from the reciprocal datal.

lysed by sonication in $50 \mathrm{mM}$ Tris- $\mathrm{HCl}(\mathrm{pH} 8) .300 \mathrm{mM} \mathrm{NaCl}$, 1\% Tergitol-type NP-40. $1 \mathrm{mM}$ phenỵlmethỵlsulphonỵl fluoride (PMSF). The lysate was clarified at $4000 \mathrm{rpm}$ for 30 nin at $+{ }^{\circ} \mathrm{C}$. The supentatant for His-tagged protein was applied by gravity flow to a column of Ni-NTA resin (PEPTRON). The resin was washed with $20 \mathrm{mM}$ Tris- $\mathrm{HCl}$ (pH 8). $500 \mathrm{mM} \mathrm{NaCl} .50 \mathrm{mM}$ imidazole and eluted with 20 nM Tris- $\mathrm{HCl}(\mathrm{pH} 8) .500 \mathrm{mM} \mathrm{NaCl}, 200 \sim 300 \mathrm{mM}$ imidazole. GST-PTP fusion proteins were affinity purified with glutathione Sepharose. Recombinant proteins were dialyzed overnight against $20 \mathrm{mM}$ Tris-HCl. $100 \mathrm{mM} \mathrm{NaCl}, 30 \%$ glycerol. $0.5 \mathrm{mM}$ PMSF before storage at $-80^{\circ} \mathrm{C}$.

In vitro PTP activity assay and kinetic analysis. The activity of phosphatases was measured using the substrate $3-0$ methylfluorescein phosphate (OMFP: Sigma) at concentrations varying with the $K_{n 1}$ of each enzyme in a 96-well microtiter plate assay based on methods described previously. ${ }^{14}$ The NSC-87877 (Calbiochen) and OMFP were solubilized in $\mathrm{H}_{2} \mathrm{O}$ and DMSO. respectively. All reactions were performed at a final concentration of $1 \%$ DMSO. The final incubation nuxture $(150 \mu \mathrm{L})$ was optimized for enzyme activity and comprised of $30 \mathrm{mM}$ Tris- $\mathrm{HCl}(\mathrm{pH} 7), 75 \mathrm{mM} \mathrm{NaCl} .1 \mathrm{mM}$ ethylenediaminetetraacetic acid (EDTA), $0.4 \mathrm{mM}$ dithiothreitol (DTT). $0.33 \%$ bovine senum albumin (BSA) and 100 nM of PTPs. Reactions were initiated by the addition of OMFP and the incubation time was $30 \mathrm{~min}$ at $37^{\circ} \mathrm{C}$. Fluorescence emission from the reaction product was measured with 
a multi-well plate reader (GENios Pro; excitation filter, 485 $\mathrm{nm}$ : emission filter. $535 \mathrm{~nm}$ ). The reaction was linear over the time period of the experiment and was directly proportional to both enzyme and substrate concentration. Half-maximal inhibition constant $\left(I C_{S c}\right)$ was defined as the concentration of an inhibitor that caused a $50 \%$ decrease in the PTP activity. Half-maximal inhibition constants and best curve fit for Lineweaver-Burk plots were determined by using the curve fitting program Prism 3.0 (GraphPad Software). All experiments were performed in triplicate and were repeated at least three times.

Acknow ledgments. This work was supported by a grant of the Korea Health 21 R\&D Project. Ministry of Health \& Welfare. Republic of Korea (01-PJ10-PG6-0IGN16-0005) and by the Korea Research Foundation Grant funded by the Korean Government (MOEHRD. Basic Research Promotion Fund) (KRF-2006-003-C00191).

\section{References}

1. Malentacchi, F.; Marzocchini, R.; Gelmini, S.; Orlando, C.; Serio, M.: Ramponi, G. Biochem. Biophys. Res. Conmmin. 2005, $33+(3), 875-883$

2. Raugei, G.: Ramponi, G.: Chiarugi, P. Cell Mol Life $S_{c i .} \mathbf{2 0 0 2 ,}$ $59(6), 941-949$

3. Alonso, A.; Sasin, I.: Bottini, N.; Friedberg, I.; Friedberg, I.; Osteman, A: Godzik, A; Hunter, T.; Dixon, T: Mustelin, T.
Cell 2004. $11766,699-711$.

4. Fischer, E. H.; Charbonneau, H.; Tonks, N. K. Science 1991, $253(5018), 401-406$

5. Fernandez-Vidal, A.: Ysebaert, L.: Didier, C.: Betous, R.: De Toni, F.: Prade-Houdellier, N.; Demur. C.: Contour-Galcera. M. O.: Prevost. G. P.: Ducommun, B.; Payrastre, B.; Racand-Sultan. C.; Manenti. S. Cancer Res. 2006, 66(14), $7128-7135$.

6. Kristiansdottir, K.: Rudolph. T. Ohem. Biol. 2004, 1/(8), 1043- 1051.

7. Ma, Z. Q.; Chua, S. S.; DeMayo, F. T.; Tsai, S. Y. Oncogene 1999. $18(32) .4564-4576$

8. Yao, Y.; Slosberg, E. D; Wang, L.; Hibshoosh, H.; Zhang, Y. T.; Xing, W. Q.; Santella, R. M.; Weinstein, I. B. Oncogene 1999, $18(37), 5159-5166$.

9. Boutros, R.; Dozier, C.; Ducommun, B. Curr: Opin. Cell Biol. $2006,18(2), 185-191$

10. Chen, L.; Sung, S. S.: Yip, M. L.; Lawrence, H. R.: Ren, Y.; Gulda, W. C.: Sebti, S. M.: Lawrence, N. J.: Wll, I. Mfol. Phamacol. 2006, 70(2), 562-570.

11. Bentires-Alj, M.; Paez, T. G.; David, F. S.; Keilhack, H.; Halmos, B.; Naoki, K.: Maris, I. M.; Richardson, A.: Bardelli, A.; Sugarbaker, D. J.: Richards, W. G.; Du, I.; Girard, L.: Minna, J. D.; Loh, M. L.; Fisher, D. E.; Velculescu, V. E.; Vogelstein, B.; Meverson, M.; Sellers, W. R.; Neel, B. G. Cancer Res. 2004, $64(24), 8816-8820$.

12. Chong, Z. Z.: Maiese, K. Histol. Histopmihol. 2007, 22(11), $1251-1267$.

13. Guo, J.: Kleeff, I.: Li, J.: Ding, T, Hammer, T.; Zhao, Y.; Giese, T.; Korc, M.; Buchler, M. W.; Friess, H. Oncogene 2004, 23(1), $71-81$.

14. Tiemo, M. B.; Tohnston, P. A.; Foster, C.; Skoko, I. J; Shinde, S. N.; Shun, T. Y.; Lazo, I. S. Nat. Protoc. 2007, 2(5), 1134-1144. 